\title{
Superior capacitive performance of hydrochar-based porous carbons in aqueous electrolytes
}

\author{
Antonio B. Fuertes, Marta Sevilla \\ Instituto Nacional del Carbón (CSIC), P.O. Box 73, Oviedo 33080, Spain \\ *Corresponding author: martasev@incar.csic.es
}

\section{Abstract}

Biomass-based highly porous carbons with an excellent performance in aqueous electrolyte-based supercapacitors have been developed. The synthesis of these materials is based on the chemical activation of biomassbased hydrochar. The addition of melamine to the activation mixture leads to porous carbons with a porosity consisting of micropores-small mesopores. Furthermore, melamine promotes the introduction of nitrogen heteroatoms in the carbon framework, along with abundant oxygen functionalities, improving the wettability. The materials produced whether in the presence or in the absence of melamine exhibit high specific capacitances in aqueous electrolytes (> $270 \mathrm{~F} \mathrm{~g}^{-1}$ in $\mathrm{H}_{2} \mathrm{SO}_{4}$ and $>190 \mathrm{~F} \mathrm{~g}^{-1}$ in $\mathrm{Li}_{2} \mathrm{SO}_{4}$ ). Besides, the mesopores present in the melamine-based micro-mesoporous carbons notably improve the ion-transport kinetics, especially in $\mathrm{Li}_{2} \mathrm{SO}_{4}$. Furthermore, in $\mathrm{Li}_{2} \mathrm{SO}_{4}$ they remain stable up to a cell voltage of $1.6 \mathrm{~V}$, exhibiting superior energy and power characteristics than in $\mathrm{H}_{2} \mathrm{SO}_{4}$.

Keywords: biomass, $\mathrm{N}$ doping, porosity 


\section{Introduction}

In view of the growing concern about the sustainability of our society and environment, biomass plays an essential role in both energy and materials production. In order to minimize the environmental impact of materials production processes, the transformation of biomass into advanced materials needs to be "green". One such process is the one referred to as hydrothermal carbonization. This consists in the thermal treatment of an aqueous solution/dispersion of an organic substance, such as saccharides or biomass, at a low temperature, normally in the $150-250{ }^{\circ} \mathrm{C}$ range. The process was first used with the purpose of fabricating a functional carbonaceous material in 2005 by Wang et al. ${ }^{[1]}$ and since then, many reports have appeared on the synthesis of carbon materials with outstanding properties by means of this methodology. [2, 3] In this field, our group has demonstrated that the carbonaceous material thus produced, denoted first by us as hydrochar, stands out as being an excellent precursor for highly porous materials since not only is a large porosity development possible, but also control over the pore size distribution and heteroatom doping. ${ }^{[4-7]}$ What is more, as recently shown, in some cases this process is the key to the successful transformation of biomass into a porous materials ${ }^{[4]}$ and it always ensures a higher yield in the activation process than pure biomass, so that less chemical activating agent is needed (with the corresponding economic and environmental advantages). ${ }^{[8]}$ In this way, advanced activated carbons have been produced from hydrochars obtained from a variety of organic substances, some of them simple such as glucose, starch or furfural, ${ }^{[6]}$ while others are more complex such as sawdust, algae or hemp. ${ }^{[4,5,9]}$ All these materials have shown excellent performances in 
environmental- and/or energy-related applications, such as hydrogen storage, ${ }^{[6]}$ $\mathrm{CO}_{2}$ capture $^{[4,5]}$ and supercapacitors. ${ }^{[7,9]}$ Nevertheless, in the case of the energy storage in supercapacitors there is still need for materials that meet the stringent energy, power, cost and duration requirements of applications such as the storage of the energy produced by renewable sources or energy storage in electric/hybrid/fuel cell vehicles. While cost requirements can be met by using biomass as precursor for electrode materials, the energy, power and duration requirements depend on the design of both the textural and chemical characteristics of the electrode materials so that they fit perfectly the type of electrolyte used. In this respect, several authors have shown that the highest energy densities are achieved when the pore size of the electrode material matches the size of the electrolyte ions (normally $0.7-0.8 \mathrm{~nm}$ ). ${ }^{[10-15]}$ However, then, the ions encounter a lot of resistance when penetrating into the pores at high rates, which results in a reduction in power density. ${ }^{[16-18]}$ To enhance both the energy and power densities, it is necessary to rationally design a pore architecture that combines narrow micropores (high energy density) with a certain number of small mesopores so as to reduce the ion-diffusion resistance (high power density). This strategy has been successfully implemented by Korenblit et al. in their use of micro/mesoporous CDCs carbons as EDLC electrodes in organic electrolyte. ${ }^{[19]}$ The surface chemistry of the electrode materials is also important as it should be compatible with the electrolyte in wettability, stability and redox activity so as to ensure not only high energy and power densities but also durability. For example, Bichat et al. have shown that a large oxygen content in porous carbon materials produces a higher capacitance and stability potential window, although substantial differences are found 
depending on the $\mathrm{pH}$ of the electrolyte used. ${ }^{[20]} \mathrm{N}$-functionalities are known to improve wettability and oxidation stability, and to give rise to redox activity especially in acidic electrolyte. ${ }^{[21-25]}$ Recently, Pinkert et al. demonstrated the effect of surface functional groups on (ionic liquid)-based carbon supercapacitors. ${ }^{[26]}$ Using a hydrophilic ionic liquid such as $\mathrm{EMIBF}_{4}$, they showed that surface chlorination significantly improves the rate capability by lowering the surface polarity. In contrast, oxygen functionalization leads to a decreased capacitance at higher power densities due to an increase in the surface polarity and the incidence of acidic protons as part of the oxygen functionalities.

Herein we show that by tuning the porosity as well as the surface chemistry of hydrochar-derived highly porous carbon materials it is possible to achieve a better matching with the electrolyte used in the supercapacitor. The methodology involves the addition of melamine to the hydrochar/ $\mathrm{KOH}$ mixture used in the chemical activation process. In this way, whereas hydrochar $/ \mathrm{KOH}$ mixtures lead to high-surface area carbons whose porosity is essentially constituted by narrow micropores $(<1 \mathrm{~nm})$ and super-micropores $(1-2 \mathrm{~nm})$, with virtually no mesopores, hydrochar $/ \mathrm{KOH} /$ melamine mixtures turn into highsurface area carbons with a bimodal porosity made up of narrow micropores $(\sim 1$ $\mathrm{nm})$ and small mesopores $(2-5 \mathrm{~nm})$. In addition, the presence of melamine in the reaction mixture leads to the incorporation of a certain number of nitrogen functional groups along with more oxygen functionalities, both of which improve the surface wettability of the carbon. In this way, even though both kinds of carbon materials perform well in aqueous electrolytes (i.e. $\mathrm{H}_{2} \mathrm{SO}_{4}$ and $\mathrm{Li}_{2} \mathrm{SO}_{4}$ ), there are substantial differences depending on the textural and chemical 
characteristics of the carbon used. Especially remarkable is the behavior of the $\mathrm{N}$-doped carbons produced from mixtures of melamine and hydrochar in the "green" electrolyte $\mathrm{Li}_{2} \mathrm{SO}_{4}$, since it is able to operate at high rates $\left(80 \mathrm{~A} \mathrm{~g}^{-1}\right)$ and in a cell voltage as high as $1.6 \mathrm{~V}$. Thus, a user-friendly supercapacitor can be produced from widely available biomass such as glucose and sawdust.

\section{Results and discussion}

Structural and chemical characteristics of the hydrochar-based porous carbons

The morphology of the porous carbons was examined by scanning electron microscopy (SEM). The SEM images displayed in Figures $1 \mathrm{a}$ and $1 \mathrm{~b}$ reveal that, independently of the synthesis route used, the carbon particles have an irregular shape with large conchoidal cavities and a smooth surface. In addition, the size of the particles is also similar, in the $10-100 \mu \mathrm{m}$ range (see Figure $\mathrm{S} 1$ in Supporting Information). The porosity of the activated carbon particles is made up of randomly distributed micropores as can be seen from the high-resolution transmission electron microscopy images in Figures $1 \mathrm{c}$ and 1d. Further analysis of the porous structure of the carbons produced in the presence (AG-M and AS-M, where $\mathrm{G}=$ glucose and $\mathrm{S}=$ sawdust) and absence of melamine (AG-0 and AS-0) by means of nitrogen physisorption reveals that the addition of melamine to the activation mixture drastically alters the porosity of the activated samples. This can be inferred from the pore size distributions (PSDs) displayed in Figures 1e and 1f. Thus, it can be seen that when the activation is carried out in the absence of melamine, the porosity of the materials (i.e. AG-0 and AS-0) consists of two pore systems made up of narrow 
micropores with a maximum at $0.85 \mathrm{~nm}$ and supermicropores with a maximum at around $1.5 \mathrm{~nm}$. In contrast, in the presence of melamine (i.e. AG-M and ASM), an enlargement of the supermicropore system is recorded and the porosity consists of two pore systems: i) narrow micropores $(0.9 \mathrm{~nm})$ and ii) small mesopores with a size of up to $\sim 4-5 \mathrm{~nm}$ and the maximum centered at around $2.2 \mathrm{~nm}$ (see Figures $1 \mathrm{e}$ and $1 \mathrm{f}$ ). Analysis of the porosity by means of the D-R method confirms that the samples obtained in the absence of melamine are essentially microporous, the micropore volume constituting more than $75 \%$ of the total pore volume, whereas the porosity of the carbons obtained in the presence of melamine is almost equally distributed between the micropores and mesopores, i.e. micropore volume/mesopore volume 1 (see Table 1). Furthermore, the textural parameters listed in Table 1 show that the AG-0 and AS-0 samples have high BET surface areas of $\sim 2700-2900 \mathrm{~m}^{2} \mathrm{~g}^{-1}$ and pore volumes of ca. $1.3-1.4 \mathrm{~cm}^{3} \mathrm{~g}^{-1}$, whereas the AG-M and AS-M samples possess ultra-high BET surface areas in the range of $3300-3400 \mathrm{~m}^{2} \mathrm{~g}^{-1}$ (AS-M) and large pore volumes of $\sim 2.2 \mathrm{~cm}^{3} \mathrm{~g}^{-1}$. Thus, the addition of melamine to the synthesis mixture considerably increases the specific surface area and, more importantly, generates a large number of small mesopores. In this way, porous carbons with ultra-high surface areas and a bimodal porosity made up of narrow micropores and small mesopores can be easily produced from widely available biomassderived products. It is worth noting that the textural properties of the different materials are similar regardless of the type of biomass used as carbon precursor, whether glucose, sawdust, cellulose or starch (data not published). 

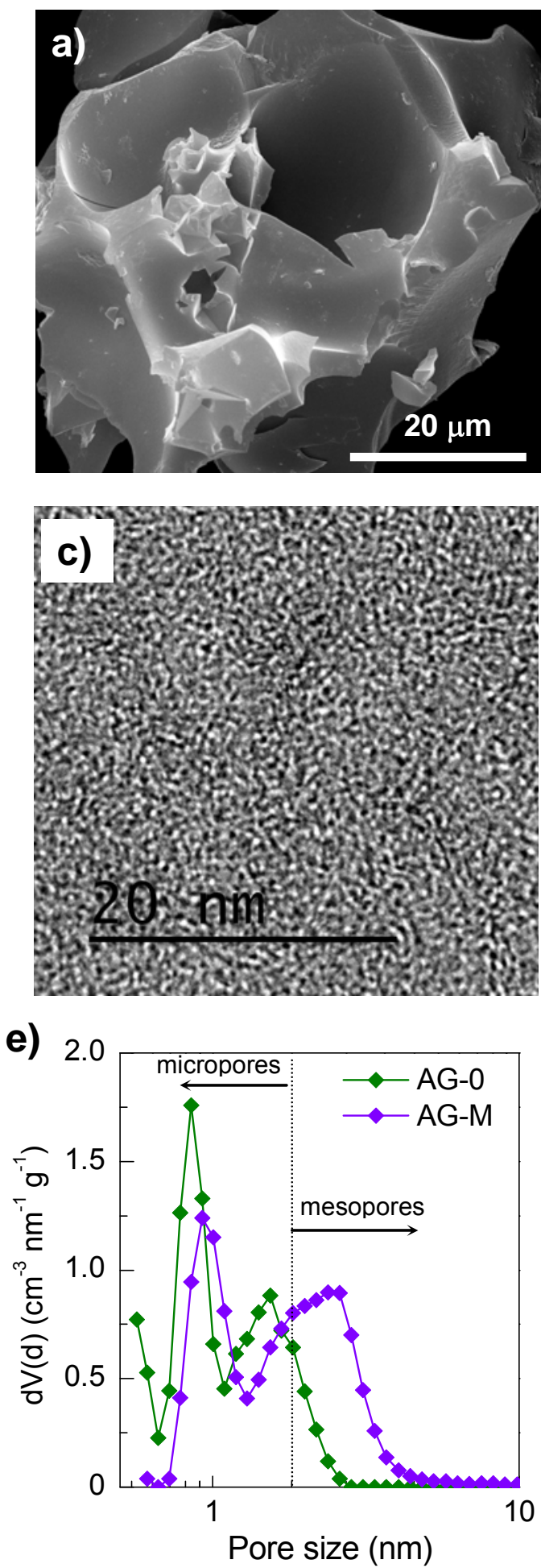
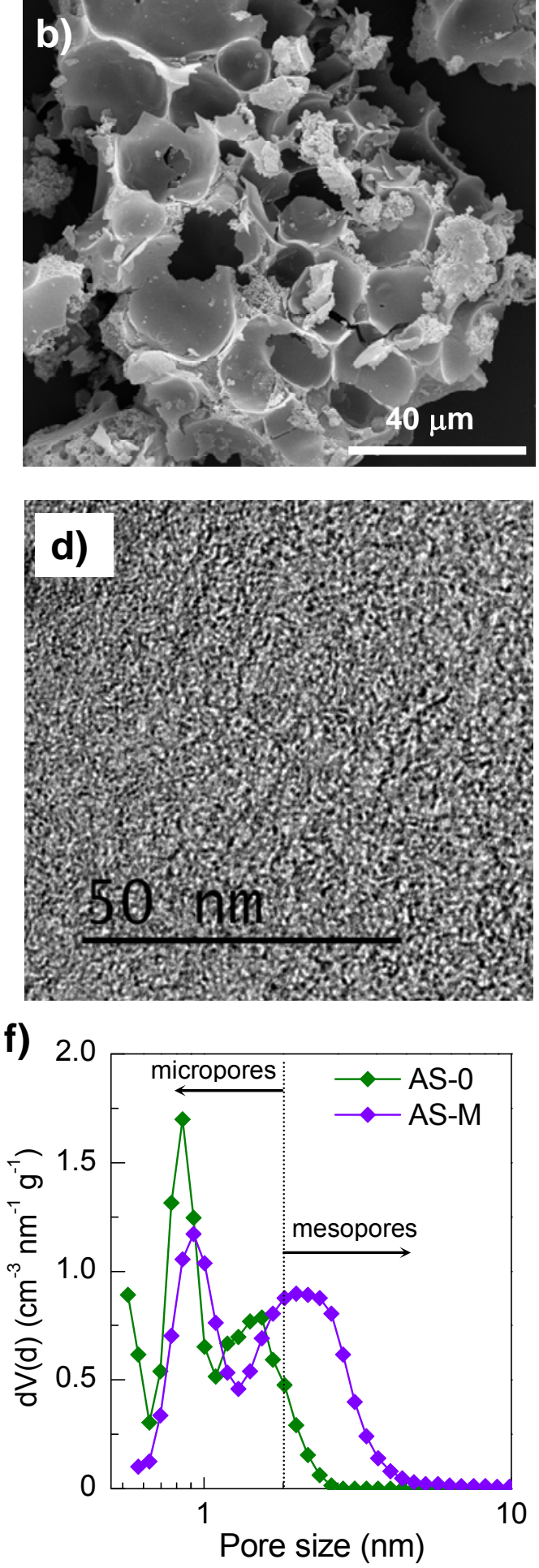

Figure 1. (a, b) SEM images of AG-0 and AG-M respectively, (c, d) HRTEM images of AS-0 and AS-M respectively, and (e, f) PSD of AG-0 and AG-M, and AS-0 and AS-M respectively. 
From a chemical point of view, the use of melamine gives rise to $\mathrm{N}$ doped porous carbons with nitrogen contents of around $1-2 \mathrm{wt} \%$, as is indicated in Table 1. These nitrogen heteroatoms originate from the decomposition of the carbon nitride $\left(g-\mathrm{C}_{3} \mathrm{~N}_{4}\right)$ formed from the polymerization of melamine at temperatures $>550{ }^{\circ} \mathrm{C}$, as we described in detail elsewhere. ${ }^{[21]}$ XPS analysis (see Figure $\mathrm{S} 2$ in Supporting Information) reveals that $\mathrm{N}$ is distributed in N-pyridinic (398.2 eV, 23 \%), N-pyrrolic/N-pyridonic (400.1 eV, 66 $\%)$, and pyridine-N-oxides (402.3 eV, $11 \%) .{ }^{[27]}$ As a consequence of their large pore volume, the carbons synthesized in the presence of melamine exhibit low packing densities and also a significant reduction in electronic conductivity owing to the loss of intraparticle connectivity. Thus, whereas the carbons produced in the absence of melamine exhibit electronic conductivities of 4.5-4.6 $\mathrm{S} \mathrm{cm}^{-1}$ and packing densities of $\sim 0.4-0.5 \mathrm{~g} \mathrm{~cm}^{-3}$, those produced with melamine show electronic conductivity values of $\sim 1.2-1.3 \mathrm{~S} / \mathrm{cm}$ and packing densities of $\sim$ $0.3 \mathrm{~g} \mathrm{~cm}^{-3}$ (see Table 1). Generally speaking, the packing density values are typical of highly activated carbons. ${ }^{[28,29]}$ The biomass-derived activated carbons exhibit similar electronic conductivities to advanced carbon materials used as electrodes in supercapacitors. This is especially true for the carbons produced in the absence of melamine. For example, they have values that are close to those reported by Ruoff's group for activated graphene $\left(5 \mathrm{~S} \mathrm{~cm}^{-1}\right),{ }^{[30]}$ to that of the conductive additive Super $\mathrm{C} 65\left(5.2 \mathrm{~S} \mathrm{~cm}^{-1}\right)$ or to that of an activated carbon specifically designed for supercapacitor applications such as Supra DLC-50 (4.3 $\mathrm{S} \mathrm{cm}^{-1}$ ). 


\section{Supercapacitor performance of the hydrochar-based porous carbons}

In the present work, the electrochemical performance of the biomassbased porous carbons was investigated in aqueous electrolytes (i.e. $\mathrm{H}_{2} \mathrm{SO}_{4}$ and $\mathrm{Li}_{2} \mathrm{SO}_{4}$ ). Galvanostatic charge/discharge cycling (CD) experiments were performed in $1 \mathrm{M} \mathrm{H}_{2} \mathrm{SO}_{4}$ electrolyte at current densities in the $0.1-150 \mathrm{~A} \mathrm{~g}^{-1}$ range. As shown in Figure 2, the specific capacitance at $0.1 \mathrm{~A} \mathrm{~g}^{-1}$ is ca. $320 \mathrm{~F} \mathrm{~g}^{-}$ ${ }^{1}$ for the carbons produced in the absence of melamine and $\sim 270-280 \mathrm{~F} \mathrm{~g}^{-1}$ for the carbons produced from mixtures of hydrochar and melamine. These values are among the highest reported for two-electrode symmetric capacitors that use aqueous electrolytes (i.e. $\mathrm{H}_{2} \mathrm{SO}_{4} / \mathrm{KOH}$ ). ${ }^{[31]}$ Furthermore, all of the activated carbons show outstanding rate capabilities, and are able to withstand an increase in the discharge current density of up to $150 \mathrm{~A} \mathrm{~g}^{-1}$, while showing with a capacitance fading as low as $\sim 45 \%$ for the carbons obtained without melamine and $\sim 35 \%$ for the materials obtained with melamine. Specific capacitance values of $170-180 \mathrm{~F} \mathrm{~g}^{-1}$ were recorded at the ultra-high current density of $150 \mathrm{~A} \mathrm{~g}^{-1}$. These values are among the highest ever recorded for

porous carbon materials in $\mathrm{H}_{2} \mathrm{SO}_{4} / \mathrm{KOH},{ }^{[8,32-38]}$ even exceeding those of many commercial activated carbons measured at low discharge rates, such as Supra DLC-50 ( $150 \mathrm{~F} \mathrm{~g}^{-1}$ at $\left.0.1 \mathrm{~A} \mathrm{~g}^{-1}\right)$. The materials obtained in the absence of melamine (i.e. AG-0 and AS-0) show higher capacitance values at low scan rates than AG-M and AS-M owing to their higher microporous surface areas $\left(\sim 2300 \mathrm{~m}^{2} \mathrm{~g}^{-1}\right.$ vs. $1700-1800 \mathrm{~m}^{2} \mathrm{~g}^{-1}$ for AG-M and AS-M, as determined by the QSDFT method). However, they exhibit lower capacitance retentions as a result of their smaller proportion of mesoporosity (see Figure 2b). When the energy and power characteristics of these carbons are examined on a Ragone plot, it 
can be seen that the performance of the materials produced in the absence of melamine is slightly superior (Figure 2c). Although their capacitance retention is smaller than that of the materials produced with melamine, this fact is compensated by their lower equivalent series resistance (ESR) -and thereby lower IR drop- as a consequence of their higher electronic conductivity. This can be clearly deduced by comparing the galvanostatic charge/discharge voltage profiles at $100 \mathrm{~A} \mathrm{~g}^{-1}$ and the Nyquist plots in Figure $2 \mathrm{~d}$. Thus, the IR drop is $0.09 \mathrm{~V}$ for $\mathrm{AG}-0$ and $0.15 \mathrm{~V}$ for $\mathrm{AG}-\mathrm{M}$ (inset in Figure $2 \mathrm{~d}$ ). The DC ESR calculated from the IR drop is $0.17 \Omega$ for AG-0 and $0.3 \Omega$ for AG-M (similar values are obtained for the sawdust-derived carbons). On the other hand, the Nyquist plot of AG-0 is shifted on the real impedance axis towards lower values in comparison to AG-M, giving an AC ESR value of $0.13 \Omega$ vs. $0.28 \Omega$ for AG-M. However, the $45^{\circ}$ Warburg region (which is related to the resistance to ion transport within the porous structure, i.e. the equivalent distributed resistance EDR) is substantially longer for AG-0 than for AG-M, resulting in an EDR value of $0.13 \Omega$ for AG-0 and $0.05 \Omega$ for AG-M. Nevertheless, the performance of all these materials is outstanding taking into account that such low IR drops at discharge rates as high as $100 \mathrm{~A} \mathrm{~g}^{-1}$ have hardly ever been reported in the literature. ${ }^{[38,39]}$ What is more, these materials are able to store up to $\sim 9-11$ Wh kg ${ }^{-1}$ at a specific power of $\sim 250 \mathrm{~W} \mathrm{~kg}^{-1}$ and still deliver 3.5-4.6 $\mathrm{Wh} \mathrm{kg}^{-1}$ at $24-33 \mathrm{~kW} \mathrm{~kg}^{-1}$ (charging time $=0.4-0.6 \mathrm{~s}$ ), placing them in the category of topperformance materials (see Figure S3a). 
a)

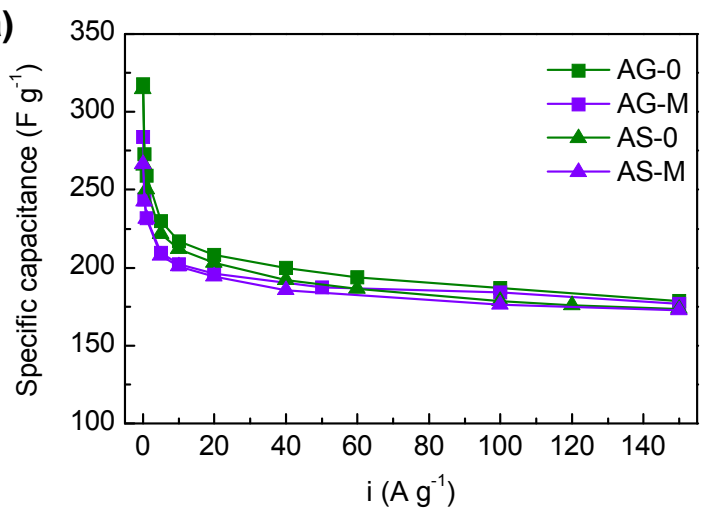

c)

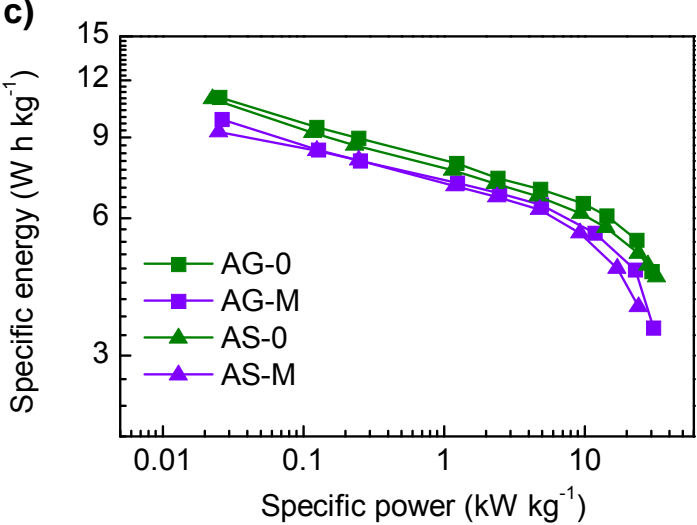

b)

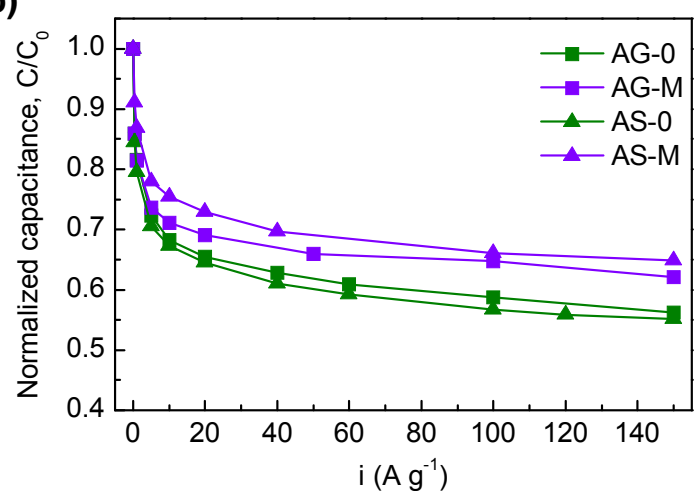

d)

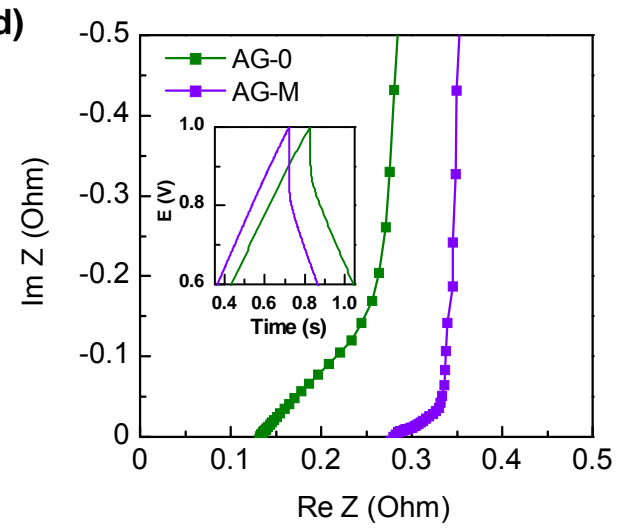

Figure 2. Rate capability of the porous carbon materials in terms of (a) specific capacitance and (b) normalized capacitance $\left(C_{0}=\right.$ capacitance at $\left.0.1 \mathrm{~A} \mathrm{~g}^{-1}\right)$. c) Ragone plot and d) Nyquist plot (inset: galvanostatic charge/discharge voltage profile at $100 \mathrm{~A} \mathrm{~g}^{-1}$ ). Electrolyte: $1 \mathrm{M} \mathrm{H}_{2} \mathrm{SO}_{4}$, cell voltage $=1 \mathrm{~V}$.

The stability of the two types of biomass-based carbon supercapacitors in $1 \mathrm{M} \mathrm{H}_{2} \mathrm{SO}_{4}$ was evaluated by $\mathrm{CD}$ experiments at $10 \mathrm{~A} \mathrm{~g}^{-1}$ over 10000 cycles at the cell voltage of $1 \mathrm{~V}$. As can be seen in Figure 3, the AG-0 carbon shows a capacitance loss of $3 \%$ coupled to an increase in the DC ESR of $6 \%$, whereas AS-M loses $2 \%$ of capacitance and undergoes an increase in DC ESR of $8 \%$. Both of these end-of-life criteria are well below the limits established by manufacturers, i.e. the initial capacitance is reduced by $20 \%$ or the ESR is increased by $100 \%,{ }^{[40]}$ confirming the robustness of the supercapacitors. 
a)

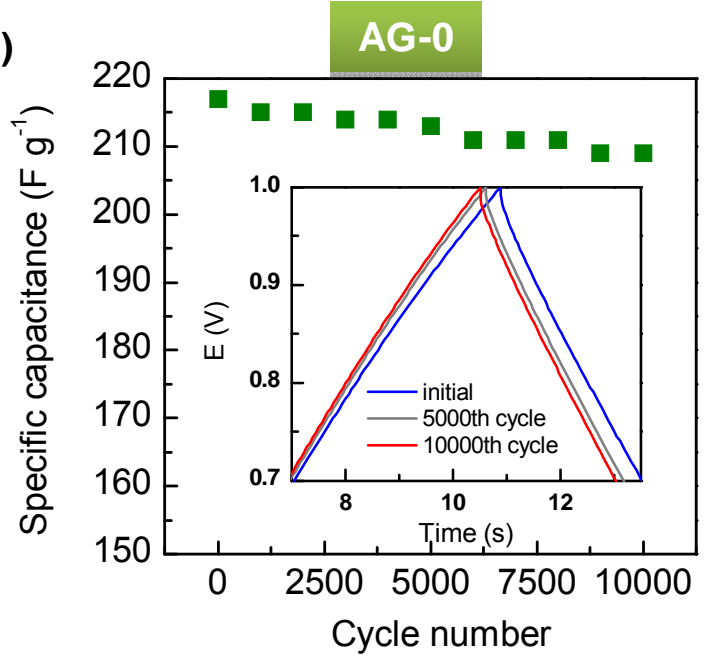

b)

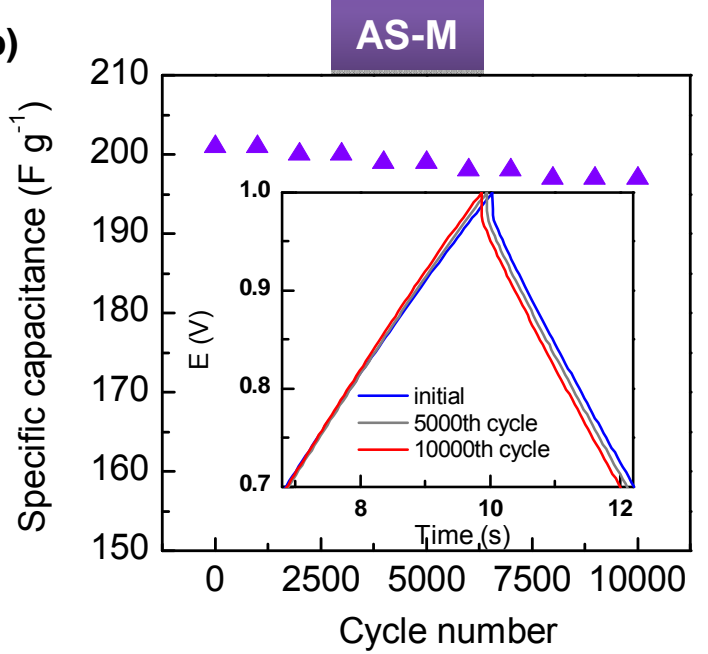

Figure 3. Long-term stability evaluated by CD experiments at $10 \mathrm{~A} \mathrm{~g}^{-1}$ for a cell voltage of $1 \mathrm{~V}$ in $1 \mathrm{M} \mathrm{H}_{2} \mathrm{SO}_{4}$ for AG-0 (a) and AS-M (b). The voltage profiles at the beginning of the test and after 5000 and 10000 cycles are provided as insets.

The electrochemical performance of these materials was also analyzed using a neutral electrolyte $\left(1 \mathrm{M} \mathrm{Li}_{2} \mathrm{SO}_{4}\right)$. This type of electrolyte was selected in view of its non-corrosive nature, environmental friendliness and the fact that alkali sulfate solutions allow operating at cell voltages in excess of $1.5 \mathrm{~V}$ in carbon/carbon symmetric systems with a good cycle life. ${ }^{[20,41-43]}$ In a first step, CD experiments were performed at a cell voltage of $1 \mathrm{~V}$, as in the case of the experiments with $\mathrm{H}_{2} \mathrm{SO}_{4}$. The results in Figure $4 \mathrm{a}$ show that at $0.1 \mathrm{~A} \mathrm{~g}^{-1}$ the specific capacitance is around $230-250 \mathrm{~F} \mathrm{~g}^{-1}$ for the carbons produced in the absence of melamine and $\sim 190-210 \mathrm{~F} \mathrm{~g}^{-1}$ for the carbons produced from mixtures of hydrochar and melamine. As for the $\mathrm{H}_{2} \mathrm{SO}_{4}$ electrolyte, AG-0 and AS-0 show higher capacitance values at low scan rates owing to their higher microporous surface areas. It can be seen that the capacitance values are in all the cases lower than in $\mathrm{H}_{2} \mathrm{SO}_{4}$, which can be attributed to the lower pseudocapacitance contribution of the oxygen/nitrogen functionalities in a neutral medium. This is evidenced by comparing the shape of the CVs and the 
CD voltage profiles in acid and neutral media (see Figure S4). Thus, perfect square shape CVs are obtained in $\mathrm{Li}_{2} \mathrm{SO}_{4}$, whereas some distortion of the square shape is noticeable in $\mathrm{H}_{2} \mathrm{SO}_{4}$ (see Figures $\mathrm{S} 4 \mathrm{a}-\mathrm{b}$ ). Likewise, the $\mathrm{CD}$ voltage profiles are highly linear in $\mathrm{Li}_{2} \mathrm{SO}_{4}$ but become curved in $\mathrm{H}_{2} \mathrm{SO}_{4}$ (see Figures $\mathrm{S} 4 \mathrm{c}-\mathrm{d}$ ). When $\mathrm{Li}_{2} \mathrm{SO}_{4}$ is used as electrolyte, however, the rate capability of the activated carbons prepared in the presence of melamine (i.e. AG-M and AS-M) is much better than that of the activated carbons produced without melamine (i.e. AG-0 and AS-0) as shown in Figures $4 a$ and $4 b$. Thus, capacitance retention at $20 \mathrm{~A} \mathrm{~g}^{-1}$ is only $50-60 \%$ for AG-0 and AS- 0 vs. $70-80 \%$ for AG-M and AS-M. Furthermore, the low DC ESR of AG-M and AS-M (1.1 $\Omega$ vs. $3.5 \Omega$ for AG-0 and AS-0) allows the discharge rate to be increased to $80 \mathrm{~A}$ $\mathrm{g}^{-1}$ while keeping $\sim 70 \%$ of the capacitance at $0.1 \mathrm{~A} \mathrm{~g}^{-1}$. Further insights into the time response and resistance of the different materials are gained by EIS studies. Indeed, Figure 4c clearly evidences the faster frequency response of AG-M and AS-M, in agreement with their higher capacitance retention with increasing discharge rate. Thus, whereas the capacitance of AG-M and AS-M reaches saturation at a frequency of $0.1 \mathrm{~Hz}$, that of $A G-0$ and $A G-S$ does not reach its limit until $\sim 0.05 \mathrm{~Hz}$. In this way, the relaxation time constant, which is considered as a factor of merit of the supercapacitor, is as low as $2.2 \mathrm{~s}$ for AG$\mathrm{M}$ and $\mathrm{AS}-\mathrm{M}$, in contrast to 8.3 for $\mathrm{AS}-0$ and $11.5 \mathrm{~s}$ for $\mathrm{AG}-0$. On the other hand, as can be deduced from the Nyquist plot (inset in Figure 4c), even though the AC ESR of AG-0 is slightly smaller than that of AG-M (0.6 $\Omega$ vs. $0.7 \Omega)$, the EDR is much larger ( $2.3 \Omega$ for AG-0 vs. $0.5 \Omega$ for AG-M), as is the resistance of the electrode/current collector interface $R_{i}(1.4 \Omega$ for AG-0 vs. $0.5 \Omega$ for AG-M). This last result suggests that surface functionality strongly influences the adhesion of 
the electrode to the current collector in $\mathrm{Li}_{2} \mathrm{SO}_{4}$. On the other hand, the much lower ionic conductivity of $1 \mathrm{M} \mathrm{Li}_{2} \mathrm{SO}_{4}\left(60 \mathrm{mS} \mathrm{cm}^{-1}\right)$ compared to that of $1 \mathrm{M}$ $\mathrm{H}_{2} \mathrm{SO}_{4}\left(1000 \mathrm{mS} \mathrm{cm}{ }^{-1}\right)$ hinders ion diffusion into the micropores, raising the value of EDR. Hence, the total resistance (i.e. ESR+Ri $+E D R$ ) of the supercapacitors prepared with AG-M and AS-M is much smaller than that of the supercapacitors prepared with AG-0 and AS-0, which agrees with the smaller IR drops recorded in the charge/discharge experiments (see Figure S5) and the higher rate capability (with discharge rates of up to $80 \mathrm{~A} \mathrm{~g}^{-1}$ ). We attribute this behavior not only to the large number of mesopores present in the AG-M and AS-M carbons, but also to their better electrolyte wettability as nitrogen and oxygen functionalities are known for increasing the surface polarity of carbon materials. ${ }^{[43,44]}$ In this respect, we observed that AG-M and AS-M were completely wetted by the electrolyte (when soaked in the electrolyte solution, they sank), whereas AG-0 and AS-0 were hardly wetted by the electrolyte (when soaked, they floated).

The activated carbons prepared from mixtures of melamine and hydrochar exhibit at $1 \mathrm{~V}$ in $\mathrm{Li}_{2} \mathrm{SO}_{4}$ a rate capability that is among the best values so far reported for a neutral electrolyte, as can be deduced from Table S1. Indeed, the superior energy and power characteristics at high rates $\left(>1 \mathrm{~kW} \mathrm{~kg}^{-}\right.$ ${ }^{1}$ ) of AG-M and AS-M in $\mathrm{Li}_{2} \mathrm{SO}_{4}$ to those of AG-0 and AS-0 are clearly illustrated in the Ragone plot represented in Figure 4d. It can be seen that a maximum specific power of $\sim 14-15 \mathrm{~kW} \mathrm{~kg}^{-1}$ (specific energy around $2 \mathrm{Wh} \mathrm{kg}^{-1}$ ) is achieved with the supercapacitors prepared with AG-M and AS-M, whereas the maximum specific power of the supercapacitors prepared with AG-0 and AS-0 is $\sim 4-7 \mathrm{~kW}$ $\mathrm{kg}^{-1}$ (specific energy ca. 2-3 $\mathrm{Wh} \mathrm{kg}^{-1}$ ). 
a)

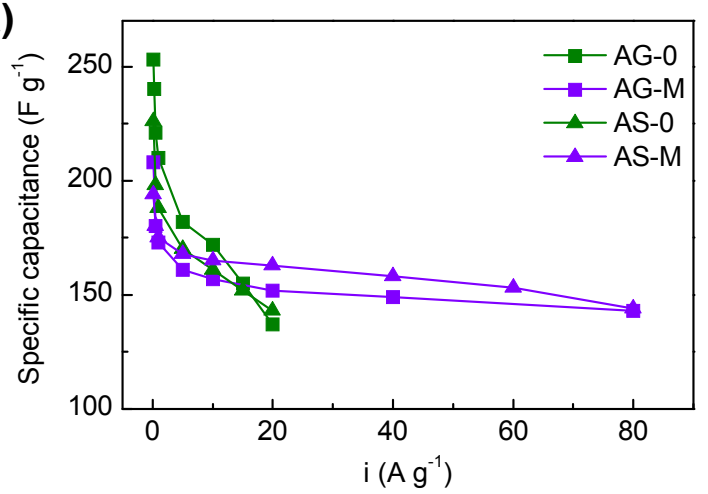

c)

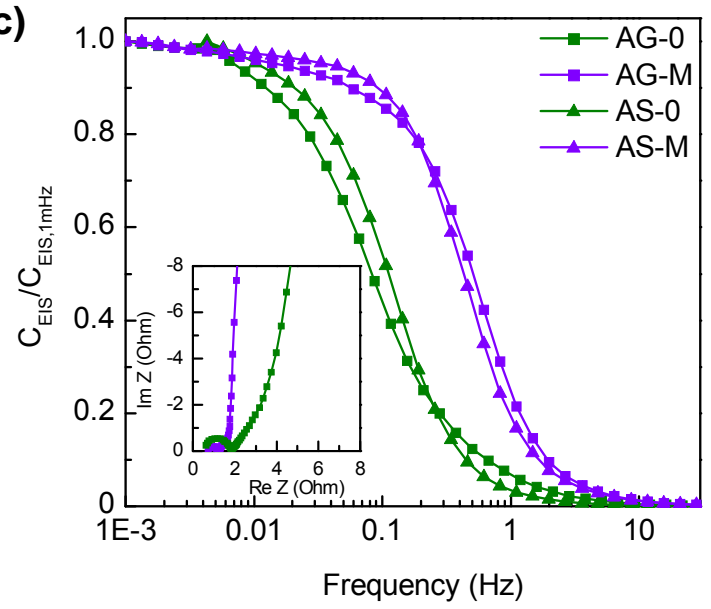

b)

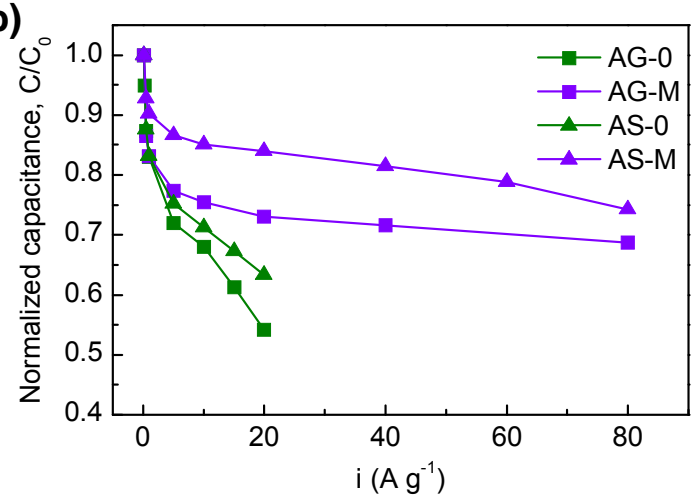

d)

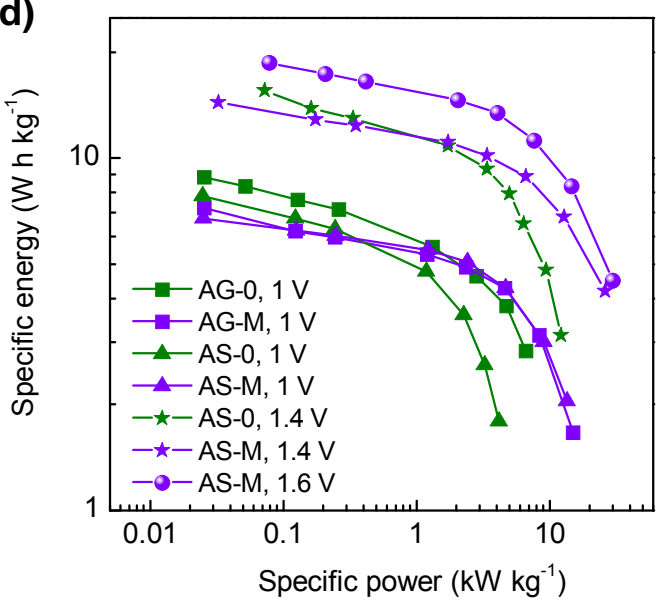

Figure 4. Rate capability of the porous carbon materials in terms of (a) specific capacitance and (b) normalized capacitance $\left(\mathrm{C}_{0}=\right.$ capacitance at $\left.0.1 \mathrm{~A} \mathrm{~g}^{-1}\right)$. c) Frequency response (inset: Nyquist plot) and d) Ragone plot. Electrolyte: $1 \mathrm{M}$ $\mathrm{Li}_{2} \mathrm{SO}_{4}$, cell voltage $=1 \mathrm{~V}$ (except otherwise stated).

To evaluate the robustness of the $\mathrm{Li}_{2} \mathrm{SO}_{4}$-based supercapacitors, 5000 galvanostatic CD cycles were carried out at $10 \mathrm{~A} \mathrm{~g}^{-1}$ and at a cell voltage of $1 \mathrm{~V}$. As can be seen in Figure S5, there is virtually no drop in capacitance nor any increase in the DC ESR evidencing the viability of these EDLC systems for long-term utilization.

Several authors have shown that commercial activated carbons can operate in symmetric capacitors with $\mathrm{Li}_{2} \mathrm{SO}_{4}$ electrolyte at cell voltages of up to 1.5 - $1.8 \vee$ with a good cycle life, i.e. over 5000-10000 galvanostatic charge/discharge cycles or for $120 \mathrm{~h}$ floating in potentiostatic conditions, owing to the greater overpotential for di-hydrogen evolution than in aqueous $\mathrm{KOH}$ or 
$\mathrm{H}_{2} \mathrm{SO}_{4}{ }^{[41,43,44,47]}$ However, only a few authors have investigated the use of biomass-derived activated carbons in this respect. ${ }^{[20,48]}$ In this work, we have studied of the working voltage window in $\mathrm{Li}_{2} \mathrm{SO}_{4}$ for sawdust-based activated carbons, i.e. AS-0 and AS-M. Long-term CD experiments (5000-15000 cycles at each cell voltage) have been carried out to evaluate the stability of the supercapacitors over different voltage windows. Figure 5 shows the evolution of capacitance with cycling for both materials at different cell voltages. For cell voltages $>1.2 \mathrm{~V}$, a clear initial increase in specific capacitance is observed. For a cell voltage of 1.2 to $1.4 \mathrm{~V}$, the capacitance enhancement is attributed to pseudocapacitance caused by hydrogen electro-sorption. This is clearly seen in the three-electrode $\mathrm{CV}$ in Figure S6a corresponding to AS-M, where dihydrogen evolution should be visible close to $-1 \mathrm{~V}$ vs. $\mathrm{Hg} / \mathrm{Hg}_{2} \mathrm{SO}_{4}$. However, instead, there is an overpotential of $>0.6 \mathrm{~V}$. The two-electrode CVs displayed in Figure S6b also show an enhancement of capacitance (similar results are obtained in the case of AS-0). For cell voltages $\geq 1.4 \mathrm{~V}$ in AS-0 and $\geq 1.5 \mathrm{~V}$ in AS-M, the initial increase of specific capacitance is ascribable to a dual factor of hydrogen electro-sorption and carbon oxidation as measured in a special twoelectrode cell provided with a reference electrode (data not shown). Similar results have been found by other authors. ${ }^{[44,49]}$ More importantly, the results in Figure $5 a$ reveal that, in the case of the AS-M sample, the loss of capacitance at cell voltages $<1.6 \mathrm{~V}$ is lower than $6 \%$ at each cell voltage after 5000 to 15000 cycles. By contrast, for the sample synthesized without melamine AS-0, the maximum working cell voltage is $1.4 \mathrm{~V}$, voltage at which the capacitance loss after 10000 cycles is around $8 \%$ (see Figure 5b). At higher cell voltages, a dramatic decrease in capacitance is recorded (see Figure 5). The different 
electrochemical stability is due to the irreversible oxidation of carbon at the working potential of the positive electrode, which is the result of the chemical differences existing between the two samples. Thus, the measured open circuit potential (OCP) of $\mathrm{AS}-0$ is displaced towards higher potentials by $0.1 \mathrm{~V}$ in comparison to that of AS-M, so that the positive electrode of AS-0 works in the 2-electrode cell at a higher potential than that of AS-M for the same cell voltage. As well, the higher initial increase of capacitance at cell voltages $>1.4-1.5 \mathrm{~V}$ in the case of AS-0 (see Figure 5b), suggests a lower oxidation resistance than that of AS-M. In this respect, we demonstrated in a previous work that $\mathrm{N}$-doping shifts carbon oxidation towards higher potentials. ${ }^{[21]}$ Likewise, Bichat et al. have shown that porous carbons with rich N/O functionalization (11.5 at.\% O and 2.6 at. $\% \mathrm{~N}$ ), and then similar to AS-M, exhibit a larger overpotential for carbon oxidation than less functionalized carbons $(7.3$ at.\% $\mathrm{O}$ and 1.4 at.\% $\mathrm{N}){ }^{[20]}$ Furthermore, Gao found that the contact between the active electrode mass and the current collector affects the stability of the supercapacitor so that a better contact ensures a larger working voltage window. ${ }^{[49]}$ 


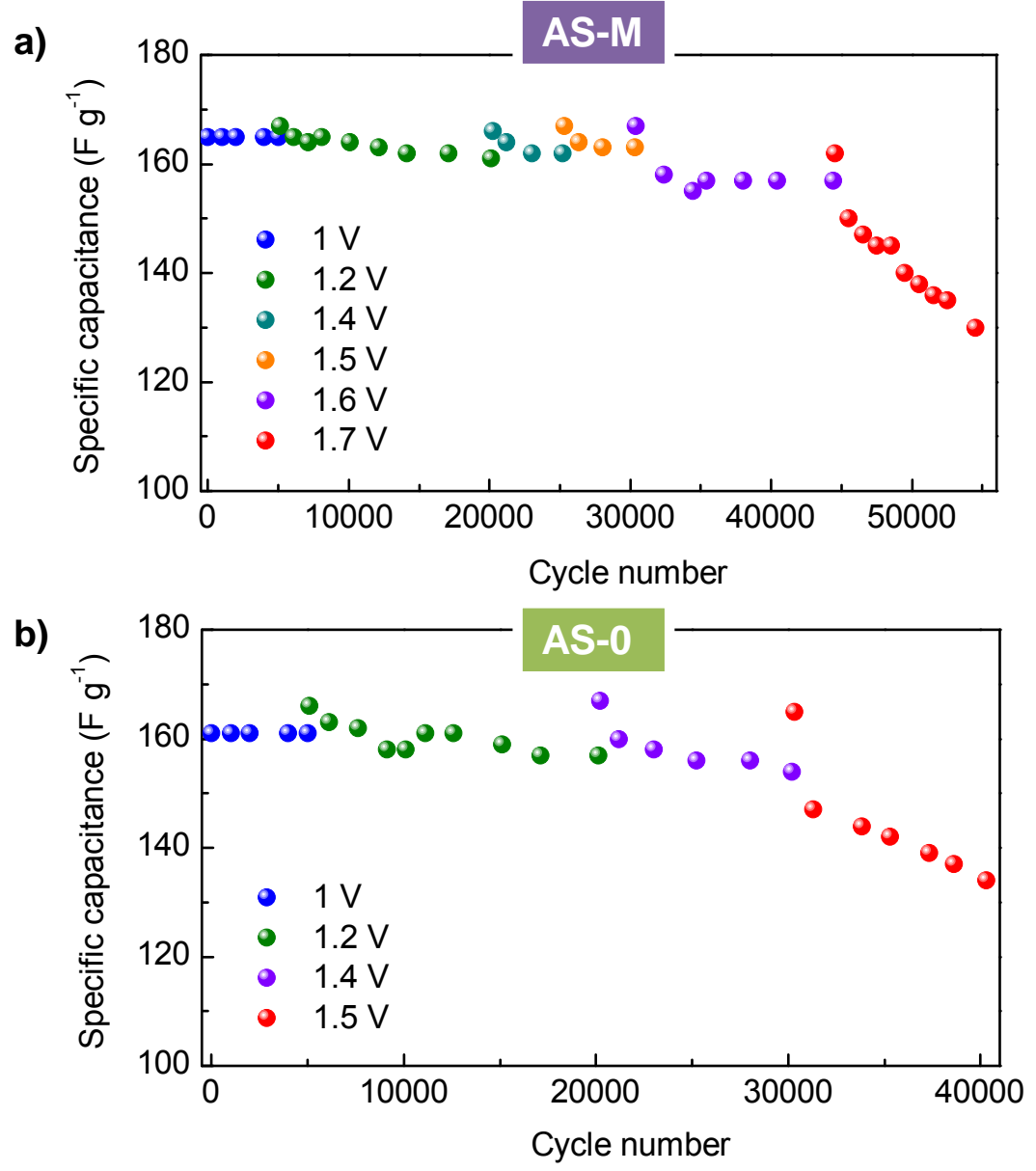

Figure 5. Long-term stability at different cell voltages in the 1.0-1.7 $\mathrm{V}$ range evaluated by CD experiments at $10 \mathrm{~A} \mathrm{~g}^{-1}$ in $1 \mathrm{M} \mathrm{Li}_{2} \mathrm{SO}_{4}$ for (a) AS-M and (b) AS0.

The energy and power characteristics of the supercapacitors are considerably improved at cell voltages $>1 \mathrm{~V}$. This is clearly illustrated by the Ragone plot represented in Figure $4 \mathrm{~d}$. Thus, in the case of the AS-0 sample at a cell voltage of $1.4 \mathrm{~V}$, the maximum energy stored increases to $15.5 \mathrm{Wh} \mathrm{kg}^{-1}$ (specific power: $73 \mathrm{~W} \mathrm{~kg}^{-1}$ ) while the maximum specific power is $12.3 \mathrm{~kW} \mathrm{~kg}^{-1}$ (energy density: $3.1 \mathrm{Wh} \mathrm{kg}^{-1}$ ). Meanwhile, in the case of the AS-M sample at a cell voltage of $1.6 \mathrm{~V}$, the maximum specific energy is $18.6 \mathrm{Wh} \mathrm{kg}^{-1}$ (specific power: $79 \mathrm{~W} \mathrm{~kg}^{-1}$ ) and the maximum specific power is $30 \mathrm{~kW} \mathrm{~kg}^{-1}$ (energy

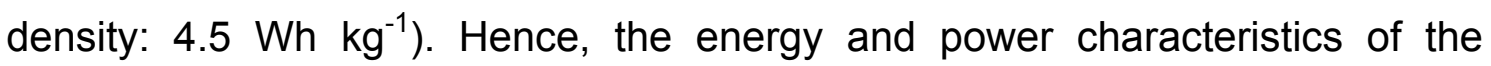


$\mathrm{Li}_{2} \mathrm{SO}_{4}$-based supercapacitors clearly surpass those of the $\mathrm{H}_{2} \mathrm{SO}_{4}$-based supercapacitors with the additional advantage of being an environmentally friendly system. Furthermore, the textural and chemical properties of the materials fabricated in the presence of melamine make their capacitive behavior in $\mathrm{Li}_{2} \mathrm{SO}_{4}$ electrolyte better than that of the materials obtained without melamine and better than that of other carbon materials reported in the literature (see Figure S3b).

\section{Conclusions}

To summarize, it has been shown that biomass-based hydrochar materials constitute an excellent "green" precursor for the synthesis of highly porous carbon materials for high-performance supercapacitors. High-surface area carbons (BET surface area $\sim 2700-3000 \mathrm{~m}^{2} \mathrm{~g}^{-1}$ ) can be produced by the $\mathrm{KOH}-$ chemical activation of hydrochar at $800^{\circ} \mathrm{C}$. With the addition of melamine to the hydrochar $/ \mathrm{KOH}$ mixture, it is possible to tune the porosity of the final carbon material from an essentially microporous material to a micro-mesoporous material (ratio micro:mesoporosity 1) with ultra-high BET surface areas (i.e. $\left.3300-3400 \mathrm{~m}^{2} \mathrm{~g}^{-1}\right)$. Furthermore, $\mathrm{N}$ heteroatoms are incorporated into the carbon framework ( 1-2 wt.\%), along with abundant oxygen functionalities, which gives rise to an improved wettability in aqueous electrolytes. Hence, although both kinds of material show an impressive performance in aqueousbased supercapacitors, substantial differences emerge as a consequence of both the textural and chemical characteristics. This is especially true in the case of using $\mathrm{Li}_{2} \mathrm{SO}_{4}$ as electrolyte. Thus, the $\mathrm{N}$-doped micro-mesoporous materials are able to work up to $80 \mathrm{~A} \mathrm{~g}^{-1}$ and retain $\sim 70 \%$ of their capacitance, whereas 
the microporous carbons can only withstand current densities of up to $20 \mathrm{~A} \mathrm{~g}^{-1}$ with a capacitance fading of $\sim 40-50 \%$. Furthermore, the N-doped micromesoporous materials are stable up to a cell voltage of $1.6 \mathrm{~V}$ versus $1.4 \mathrm{~V}$ in the case of the microporous carbons as a result of a better contact between the electrodes and the current collector and a higher oxidation resistance resulting from the rich functionalization. In the $\mathrm{H}_{2} \mathrm{SO}_{4}$ electrolyte, an outstanding rate capability is registered for both kinds of carbons, which are able to operate up to $150 \mathrm{~A} \mathrm{~g}^{-1}$ with a low capacitance fading of $\sim 35-45 \%$. At a low discharge rate of $0.1 \mathrm{~A} \mathrm{~g}^{-1}$, large specific capacitances of up to ca. $320 \mathrm{~F} \mathrm{~g}^{-1}$ are obtained in the case of the microporous carbons and $\sim 270-280 \mathrm{~F} \mathrm{~g}^{-1}$ in the case of the micromesoporous carbons in $\mathrm{H}_{2} \mathrm{SO}_{4}$ electrolyte. Specific capacitances of 230-250 F $\mathrm{g}^{-1}$ and $\sim 190-210 \mathrm{~F} \mathrm{~g}^{-1}$ are achieved at $0.1 \mathrm{~A} \mathrm{~g}^{-1}$ in the case of the microporous and micro-mesoporous carbons respectively in $\mathrm{Li}_{2} \mathrm{SO}_{4}$ electrolyte.

\section{Experimental}

\section{Synthesis of the materials}

Hydrochar products were prepared by hydrothermal carbonization of glucose (Aldrich) and eucalyptus sawdust (Local sawmill). Briefly, an aqueous solution/dispersion of the raw material (concentration: $320 \mathrm{~g} \mathrm{~L}^{-1}$ ) was placed in a Teflon-lined stainless steel autoclave, heated up to $250{ }^{\circ} \mathrm{C}$ and kept at this temperature for $2 \mathrm{~h}$. The resulting carbonaceous solid, denoted as hydrochar, was recovered by filtration, washed with distilled water and dried at $120{ }^{\circ} \mathrm{C}$ for several hours. 
The hydrochar materials were chemically activated using potassium hydroxide (Sigma-Aldrich) in the presence of melamine (Aldrich). With this aim, a hydrochar sample was thoroughly ground with $\mathrm{KOH}(\mathrm{KOH} /$ Hydrochar weight ratio of 4) and melamine (melamine/Hydrochar weight ratio of 2), heat-treated up to $800{ }^{\circ} \mathrm{C}$ (heating rate: $3^{\circ} \mathrm{C} \mathrm{min}-1$ ) under a nitrogen gas flow and held at this temperature for $1 \mathrm{~h}$. The samples were then thoroughly washed several times with $10 \mathrm{wt} . \% \mathrm{HCl}$, distilled water and finally dried in an oven at $120^{\circ} \mathrm{C}$ for $3 \mathrm{~h}$. The activated carbons thus synthesized were denoted as $A X-M$, where $X$ refers to the raw material (G: glucose and S: sawdust). Porous carbons were also produced in the absence of melamine by $\mathrm{KOH}$ activation of the hydrochar materials $(\mathrm{KOH} / \mathrm{Hydrochar}$ weight ratio of 4$)$ at a temperature of $800^{\circ} \mathrm{C}$. These samples were denoted as $A X-O$.

\section{Characterization}

The textural characteristics of the samples, namely the Brunauer-Emmett-Teller (BET) surface area, pore size distribution, and pore volume were determined by nitrogen physisorption at $-196{ }^{\circ} \mathrm{C}$ (Micromeritics ASAP 2020 sorptometer). The apparent surface area was calculated using the BET method. An appropriate relative pressure range was selected to ensure that a positive line intersect of multipoint BET fitting $(C>0)$ would be obtained and $V_{a d s}\left(1-p / p_{o}\right)$ would increase with p/po. ${ }^{[50]}$ The total pore volume was determined from the amount of nitrogen adsorbed at a relative pressure $\left(P / P_{0}\right)$ of 0.95 , whereas the micropore volume was determined using the Dubinin-Radushkevich equation. ${ }^{[51]}$ The pore size distributions (PSD) were determined by means of the Quench Solid State Density Functional Theory (QSDFT) method for nitrogen. [52, 53] Scanning electron microscopy (SEM) images were obtained on a Quanta 
FEG650 (FEI) instrument. Transmission electron micrographs (TEM) were taken on a JEOL (JEM 2100-F) apparatus operating at $200 \mathrm{kV}$. Elemental analysis (C, N and O) of the samples was carried out on a LECO CHN-932 microanalyzer. The dc electrical conductivity and the packing density of the carbon powders were determined on a home-made apparatus (four-probe method) by pressing the powders between two plungers into a hollow Nylon cylinder (inner diameter of $8 \mathrm{~mm}$ ), and applying a pressure of $7.1 \mathrm{MPa}$.

\section{Electrochemical measurements}

The electrodes were composed of $85 \mathrm{wt} \%$ active material, $10 \mathrm{wt} \%$ polytetrafluoroethylene (PTFE) binder (Aldrich, $60 \mathrm{wt} \%$ suspension in water) and $5 \%$ Super P (Timcal). The electrochemical measurements were performed in two-electrode Swagelok ${ }^{\mathrm{TM}}$ type cells using stainless steel current collectors with $1 \mathrm{M} \mathrm{Li}_{2} \mathrm{SO}_{4}$ and gold current collectors in the case of $1 \mathrm{M} \mathrm{H}_{2} \mathrm{SO}_{4}$. The electrochemical capacitors were assembled using two carbon electrodes of comparable mass and thickness $(150-200 \mu \mathrm{m})$, electrically isolated by a glassy fibrous separator. The electrochemical characterization was performed using a computer-controlled potentiostat (Biologic VMP3 multichannel generator) and consisted of cyclic voltammetry experiments, electrochemical impedance spectroscopy studies (EIS) and galvanostactic charge/discharge cycling tests.

Cyclic voltammetry experiments (CVs) were performed between 0 and 1$1.8 \mathrm{~V}$ at increasing sweep rates from $1 \mathrm{mV} \mathrm{s}^{-1}$ to $2 \mathrm{~V} \mathrm{~s}^{-1}$. Plots of specific capacitance vs. voltage were calculated using the formula:

$$
\mathrm{C}_{\mathrm{sp}}=\frac{2 \cdot 1}{v \cdot \mathrm{m}}
$$


Where $\mathrm{I}=$ current $(\mathrm{A}), \quad=$ scan rate $\left(\mathrm{V} \mathrm{s}^{-1}\right)$ and $\mathrm{m}=$ mass $($ grams $)$ of carbon material in one electrode.

Galvanostatic charge/discharge cycling was performed in the same voltage range at increasing current densities from 0.1 to $150 \mathrm{~A} \mathrm{~g}^{-1}$, based on the active mass of one electrode. The specific gravimetric capacitance of one electrode determined from the galvanostatic cycles was calculated by means of the formula:

$$
\mathrm{C}_{\mathrm{sp}}=\frac{2 \cdot 1}{(\mathrm{dV} / \mathrm{dt}) \cdot \mathrm{m}}
$$

where $\mathrm{dV} / \mathrm{dt}=$ the slope of the discharge curve $\left(\mathrm{V} \mathrm{s}^{-1}\right)$.

To trace the Ragone plots, the specific energy $\left(\mathrm{Wh} \mathrm{kg}^{-1}\right)$ and power $\left(\mathrm{kW} \mathrm{kg}^{-1}\right)$ were calculated using the following formulae:

$$
\begin{aligned}
& E=\frac{1}{2} C_{c e l l} \Delta V_{d}^{2} \\
& P=\frac{E}{\Delta t_{d}}
\end{aligned}
$$

where $C_{c e l l}$ is the specific capacitance of the total cell $\left(F g^{-1}\right), \Delta V_{d}$ is the operation voltage $\left(V_{\max }-I R_{\text {drop }}\right)$ and $\Delta_{t d}$ is the discharge time.

Electrochemical impedance spectroscopy (EIS) measurements were performed at open circuit voltage (i.e. $0 \mathrm{~V}$ ) within the frequency range of $1 \mathrm{mHz}$ to $100 \mathrm{kHz}$ and a $10 \mathrm{mV}$ AC amplitude. Plots of the dependence of the capacitance on frequency and Nyquist plots were recorded to characterize the impedance of the tested samples. The specific gravimetric capacitance of a single electrode, $\mathrm{C}_{\mathrm{EIS}}(\mathrm{F} / \mathrm{g})$, was calculated according to the following formula and normalized with respect to the specific gravimetric capacitance at $1 \mathrm{mHz}$ : 


$$
C_{E I S}=\frac{2 \cdot|\operatorname{Im}(Z)|}{2 \pi \pi\left[(\operatorname{Im}(Z))^{2}+(\operatorname{Re}(Z))^{2}\right] \cdot m}
$$

where $f$ is the operating frequency $(\mathrm{Hz})$, and $\operatorname{Im}(Z)$ and $\operatorname{Re}(Z)$ are the imaginary and real components of the total device resistance (Ohm). The relaxation time constant, $\tau_{0}$, which separates the capacitive behavior and the resistive behavior of the supercapacitor, was deduced from the frequency $f_{0}$ as follows: $\tau_{0}=1 / f_{0}$, where $f_{0}$ is obtained from the real capacitance plot at $C^{\prime}=C_{1 \mathrm{mHz}} / 2$. The equivalent series resistance (ESR) was calculated from the intercept of the high frequency semicircle loop with the real impedance axis at the highest frequency. ${ }^{[54,55]}$ The resistance of the electrode/current collector interface $\left(R_{i}\right)$ was calculated from the second intercept of the high frequency semicircle loop with the real impedance axis (after subtraction of the ESR). ${ }^{[55]}$ The equivalent distributed resistance (EDR) was determined from the linear projection of the vertical portion at low frequencies to the real axis (after subtraction of the ESR and $\left.\mathrm{R}_{\mathrm{i}}\right)^{[54]}$

Acknowledgments. This research work was supported by the Spanish MINECO (MAT2012-31651). M. S. thanks the Spanish MINECO for her Ramón y Cajal contract.

\section{References}

[1] Q. Wang, H. Li, L. Chen, X. Huang, Carbon 2001, 39, 2211-2214.

[2] M. M. Titirici, M. Antonietti, Chem. Soc. Rev. 2010, 39, 103-116.

[3] M.-M. Titirici, R. J. White, C. Falco, M. Sevilla, Energy Environ. Sci. 2012, 5, 6796-6822.

[4] M. Sevilla, C. Falco, M.-M. Titirici, A. B. Fuertes, RSC Adv. 2012, 2, 12792-12797.

[5] M. Sevilla, A. B. Fuertes, Energy Environ. Sci. 2011, 4, 1765-1771.

[6] M. Sevilla, A. B. Fuertes, R. Mokaya, Energy Environ. Sci. 2011, 4, 1400-1410.

[7] L. Wei, M. Sevilla, A. B. Fuertes, R. Mokaya, G. Yushin, Adv. Energy Mater. 2011, 1, 356-361.

[8] M. Sevilla, L. Yu, C. O. Ania, M.-M. Titirici, ChemElectroChem 2014, n/a-n/a. 
[9] H. Wang, Z. Xu, A. Kohandehghan, Z. Li, K. Cui, X. Tan, T. J. Stephenson, C. K. King'ondu, C. M. B. Holt, B. C. Olsen, J. K. Tak, D. Harfield, A. O. Anyia, D. Mitlin, ACS Nano 2013, 7, 5131-5141.

[10] C. O. Ania, J. Pernak, F. Stefaniak, E. Raymundo-Piñero, F. Béguin, Carbon 2006, 44, 3126-3130.

[11] C. Largeot, C. Portet, J. Chmiola, P.-L. Taberna, Y. Gogotsi, P. Simon, J. Am. Chem. Soc. 2008, 130, 2730-2731.

[12] C. Vix-Guterl, E. Frackowiak, K. Jurewicz, M. Friebe, J. Parmentier, F. Béguin, Carbon 2005, 43, 1293-1302.

[13] E. Raymundo-Piñero, K. Kierzek, J. Machnikowski, F. Béguin, Carbon 2006, 44, 2498-2507.

[14] J. Chmiola, G. Yushin, Y. Gogotsi, C. Portet, P. Simon, P. L. Taberna, Science 2006, 313, 1760-1763.

[15] J. Chmiola, C. Largeot, P.-L. Taberna, P. Simon, Y. Gogotsi, Angew. Chem. Int. Ed. 2008, 47, 3392-3395.

[16] M. Sevilla, A. B. Fuertes, ACS Nano 2014, 8, 5069-5078.

[17] J. Leis, M. Arulepp, M. Käärik, A. Perkson, Carbon 2010, 48, 4001-4008.

[18] J. Chmiola, G. Yushin, R. Dash, Y. Gogotsi, J. Power Sources 2006, 158, 765-772.

[19] Y. Korenblit, M. Rose, E. Kockrick, L. Borchardt, A. Kvit, S. Kaskel, G. Yushin, ACS Nano 2010, 4, 1337-1344.

[20] M. P. Bichat, E. Raymundo-Piñero, F. Béguin, Carbon 2010, 48, 4351-4361.

[21] A. B. Fuertes, G. A. Ferrero, M. Sevilla, J. Mater. Chem. A 2014, 2, 14439-14448.

[22] Y.-H. Lee, K.-H. Chang, C.-C. Hu, J. Power Sources 2013, 227, 300-308.

[23] S. L. Candelaria, B. B. Garcia, D. Liu, G. Cao, J. Mater. Chem. 2012, 22, 98849889.

[24] E. Frackowiak, G. Lota, J. Machnikowski, C. Vix-Guterl, F. Béguin, Electrochim. Acta 2006, 51, 2209-2214.

[25] G. Lota, B. Grzyb, H. Machnikowska, J. Machnikowski, E. Frackowiak, Chem. Phys. Lett. 2005, 404, 53-58.

[26] K. Pinkert, M. Oschatz, L. Borchardt, M. Klose, M. Zier, W. Nickel, L. Giebeler, S. Oswald, S. Kaskel, J. Eckert, ACS App. Mater. Interfases 2014, 6, 2922-2928.

[27] J. R. Pels, F. Kapteijn, J. A. Moulijn, Q. Zhu, K. M. Thomas, Carbon 1995, 33, 1641-1653.

[28] Y. Gogotsi, P. Simon, Science 2011, 334, 917-918.

[29] S. Murali, N. Quarles, L.L. Zhang, J.R. Potts, Z. Tan, Y. Lu, Y. Zhu, R.S. Ruoff, Nano Energy 2013, 2, 764-768.

[30] Y. Zhu, S. Murali, M. D. Stoller, K. J. Ganesh, W. Cai, P. J. Ferreira, A. Pirkle, R. M. Wallace, K. A. Cychosz, M. Thommes, D. Su, E. A. Stach, R. S. Ruoff, Science 2011, 332, 1537-1541.

[31] M. Sevilla, R. Mokaya, Energy Environ. Sci. 2014, 7, 1250-1280.

[32] Y. Li, Z. Li, P. K. Shen, Adv. Mater. 2013, 25, 2474-2480.

[33] Y. S. Yun, S. Y. Cho, J. Shim, B. H. Kim, S.-J. Chang, S. J. Baek, Y. S. Huh, Y. Tak, Y. W. Park, S. Park, H.-J. Jin, Adv. Mater. 2013, 25, 1993-1998.

[34] L. Qie, W. Chen, H. Xu, X. Xiong, Y. Jiang, F. Zou, X. Hu, Y. Xin, Z. Zhang, Y. Huang, Energy Environ. Sci. 2013, 6, 2497-2504.

[35] D. Puthusseri, V. Aravindan, S. Madhavi, S. Ogale, Energy Environ. Sci. 2014, 7, 728-735.

[36] L. Sun, C. Tian, M. Li, X. Meng, L. Wang, R. Wang, J. Yin, H. Fu, J. Mater. Chem. A 2013, 1, 6462-6470. 
[37] M. Li, C. Liu, H. Cao, H. Zhao, Y. Zhang, Z. Fan, J. Mater. Chem. A 2014, 2, 14844-14851.

[38] Y. Tan, C. Xu, G. Chen, Z. Liu, M. Ma, Q. Xie, N. Zheng, S. Yao, ACS App. Mater. Interfases 2013, 5, 2241-2248.

[39] Z.-Y. Jin, A.-H. Lu, Y.-Y. Xu, J.-T. Zhang, W.-C. Li, Adv. Mater. 2014, 26, 37003705.

[40] M. Technologies, “Application Note, Life Duration Estimation”. $<$ http://www.maxwell.com>

[41] P. Ratajczak, K. Jurewicz, F. Béguin, J. Appl. Electrochem. 2014, 44, 475-480.

[45] L. Demarconnay, E. Raymundo-Piñero, F. Béguin, Electrochem. Commun. 2010, $12,1275-1278$.

[43] K. Fic, G. Lota, M. Meller, E. Frackowiak, Energy Environ. Sci. 2012, 5, 58425850 .

[44] Q. Gao, L. Demarconnay, E. Raymundo-Pinero, F. Beguin, Energy Environ. Sci. 2012, 5, 9611-9617.

[45] W. Xiong, M. Liu, L. Gan, Y. Lv, Z. Xu, Z. Hao, L. Chen, Colloids Surf., A 2012, 411, 34-39.

[46] T. Kwon, H. Nishihara, H. Itoi, Q.-H. Yang, T. Kyotani, Langmuir 2009, 25, 11961-11968.

[47] X. Sun, X. Zhang, H. Zhang, D. Zhang, Y. Ma, J. Solid State Electrochem. 2012, $16,2597-2603$.

[48] D. Jiménez-Cordero, F. Heras, M. A. Gilarranz, E. Raymundo-Piñero, Carbon 2014, 71, 127-138.

[49] Q. Gao, PhD Thesis, Université d'Orléans (France), 2013.

[50] ISO 9277:2010. Determination of the specific surface area of solids by gas adsorption - BET method. Second Edition of ISO 9277, ISO, Vol. (Ed.^ Eds.: Editor), City, 2012.

[51] M. M. Dubinin, Carbon 1989, 27, 457-467.

[52] A. V. Neimark, Y. Lin, P. I. Ravikovitch, M. Thommes, Carbon 2009, 47, $1617-$ 1628.

[53] P. I. Ravikovitch, A. V. Neimark, Langmuir 2006, 22, 11171-11179.

[54] R. Kötz, M. Carlen, Electrochim. Acta 2000, 45, 2483-2498.

[55] C. Portet, P. L. Taberna, P. simon, C. Laberty-Robert, Electrochim. Acta 2004, 49, 905-912. 
Table 1. Physical and chemical properties of the hydrochar-based KOH activated carbons.

\begin{tabular}{|c|c|c|c|c|c|c|c|c|c|c|}
\hline \multirow{2}{*}{$\begin{array}{l}\text { Hydrochar } \\
\text { precursor }\end{array}$} & \multirow{2}{*}{$\begin{array}{l}\text { Sample } \\
\text { code }\end{array}$} & \multicolumn{4}{|c|}{ Textural properties } & \multicolumn{3}{|c|}{ Chemical composition (wt \%) } & \multirow{2}{*}{$\begin{array}{l}\text { Conductivity } \\
\left(\mathrm{S} \mathrm{cm}^{-1}\right)^{\mathrm{d}}\end{array}$} & \multirow{2}{*}{$\begin{array}{l}\text { Packing density } \\
\left(\mathrm{g} \mathrm{cm}^{-3}\right)^{\mathrm{d}}\end{array}$} \\
\hline & & $\mathrm{S}_{\mathrm{BET}}\left(\mathrm{m}^{2} \mathrm{~g}^{-1}\right)$ & $V_{p}\left(\mathrm{~cm}^{3} \mathrm{~g}^{-1}\right)^{a}$ & $V_{\text {micro }}\left(\mathrm{cm}^{3} \mathrm{~g}^{-1}\right)^{b}$ & $V_{\text {meso }}\left(\mathrm{cm}^{3} \mathrm{~g}^{-1}\right)^{\mathrm{c}}$ & $\mathrm{N}$ & $\mathrm{C}$ & $\mathrm{O}$ & & \\
\hline \multirow[t]{2}{*}{ Glucose } & AG-0 & 2950 & 1.36 & 1.02 & $0.34(25)$ & 0.2 & 93.3 & 6.3 & 4.6 & 0.41 \\
\hline & AG-M & 3300 & 2.25 & 1.20 & $1.05(47)$ & 2.1 & 86.9 & 10.7 & 1.2 & 0.28 \\
\hline \multirow[t]{2}{*}{ Sawdust } & AS-0 & 2690 & 1.28 & 1.00 & $0.28(22)$ & 0.1 & 95.4 & 4.4 & 4.5 & 0.47 \\
\hline & AS-M & 3420 & 2.30 & 1.16 & $1.14(50)$ & 1.3 & 89.6 & 8.8 & 1.3 & 0.26 \\
\hline
\end{tabular}

${ }^{a}$ Pore volume at $\mathrm{p} / \mathrm{p}_{\mathrm{o}} \sim 0.95 .{ }^{\mathrm{b}}$ Micropore volume determined by the $\mathrm{D}-\mathrm{R}$ method. ${ }^{\mathrm{c}}$ Mesopore volume deduced from the difference between the pore volume $\left(V_{p}\right)$ and the micropore volume $\left(V_{\text {micro }}\right)$; the percentage of pore volume that corresponds to the mesopores is given in parenthesis. ${ }^{d}$ Pressure load $=7.1 \mathrm{MPa}$. 


\section{FULL PAPER}

$\mathrm{N}$-doped carbons produced from mixtures of melamine and hydrochar show outstanding capacitive behaviour in aqueous electrolytes, i.e. $\mathrm{H}_{2} \mathrm{SO}_{4}$ (cell voltage $=1 \mathrm{~V}$ ) and $\mathrm{Li}_{2} \mathrm{SO}_{4}$ (cell voltage $=1.6 \mathrm{~V})$.

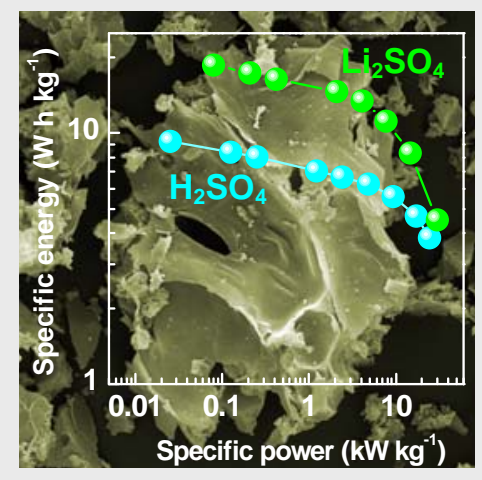

Antonio b. Fuertes, Marta Sevilla*

Page No. - Page No.

Superior capacitive performance of hydrochar-based porous carbons in aqueous electrolytes 